\title{
STUDY OF PATHOGENICITY AND IMMUNOGENICITY OF PASTEURELLA MULTOCIDA RECENTLY ISOLATED FROM INFECTED RABBITS
}

\author{
ELHAM A. YOUSSEF
}

Veterinary Serum and Vaccine Research Institute, Abbasia, Cairo, ARC, Ministry of Agriculture, Dokki, Giza

(Manuscript received 22 December 2010)

\begin{abstract}
In this study, 150 samples were collected from rabbits in infected farms which show high mortality suspected to be affected with Pasteurellosis. Thirty of Pasteurella multocida isolates were obtained which were belonged to serotypes $A: 3, A: 3,5, A: 12, B: 2$, $D: 6$ and uncommon types as A:4 and D:12. The determination of pathogenicity and immunogenicity of these isolates (in mice) indicated that some of these isolates were highly pathogenic, others are of moderate or low pathogenicity. The protective value was good in serotypes A:3, A:3,5, A:12, B:2, D:6 which gave high protective value (more than $2 \mathrm{log}$ ), when vaccinated mice were challenged with homologous strains. Rabbits vaccinated with currently used vaccine and challenged with homologous strains and heterologous recently isolates gave good immune response except with field serotypes $\mathrm{B}: 2$ and $\mathrm{D}: 6$.
\end{abstract}

\section{INTRODUCTION}

Pasteurellosis remains a major problem in many commercial rabbitries. Manifestations of Pasteurella multocida ( $P$. multocida) infections in rabbits include "snuffles", bronchopneumonia, middle ear infections, abscessation, conjunctivitis, mastitis, reproductive tract infections and acute fatal systemic infections (Percy and Bhasin, 1987). This disease causes serious lesions in small breeding and larger farms. Consequently, investigation on the development of effective control and preventive methods are of a vital importance.

Pasteurella multocida of rabbit origin had received many studies, of which are types $A$ and $D$ to be common in rabbits and others are types $B$ and $C$ which are most prevalent (Hagen, 1966). at the same time, a study reported from Japan, found capsular type A from rabbit in holding colony, while a report from United States found that capsular types $A$ and $D$ were most common in rabbits from the wide west region (Chengappa et al., 1982). So, we need extensive study for P. multocida of rabbits and carrying out survey from time to time to determine any different capsular and somatic components in field isolates which may be found.

The aim of this study was done to determine the antigenic structure of recently isolated $P$. multocida from rabbits and to estimate its pathogenicity and 
immunogenicity to select the ideal isolates to be added or not to the currently produced vaccine in the future.

\section{MATERIALS AND METHODS}

Samples were collected from 150 diseased and recently dead rabbits in different farms of different localities in Egypt. The samples were in the form of nasal swabs, middle ear and internal organs. Rabbits in these farms were suffereing from illness and high mortality which may be due to Pasteurella infection. The samples were subjected to bacteriological and biochemical identification.

\section{Serological typing of recent isolates of $\boldsymbol{P}$, multocida}

1. Capsular typing of $\boldsymbol{P}$. multocida : This was performed according to Carter (1955).

2. Somatic typing of $\boldsymbol{P}$. multocida : This was done according to Heddleston et al. (1972).

\section{Laboratory animals used}

Mice

One thousand and seventy five 1675 healthy Swiss albino mice each weighing 18-22 $\mathrm{g}$ were obtained from the mice farm the at Veterinary Serum and Vaccine Research Institute, Abbasia, Cairo, and used for determination of pathogenicity and immunogenicity of recent rabbit Pasteurella field isolates.

Determination of pathogenicity and immunogenicity of recently isolated $\boldsymbol{P}$. multocida of rabbits origin

\section{Determination of the minimum lethal dose $\left(L D_{50}\right)$ of $P_{\text {. }}$ multocida in mice}

Recent field isolates of $P$. multocida strains were cultivated on nutrient agar plates and incubated at $37^{\circ} \mathrm{C}$ for 24 hours, and the harvested cells were suspended in sterile saline in density equal to $5 \times 10^{9}$ bacterial cell. The bacterial cell suspensions were serially ten fold diluted from $10^{-1}$ to $10^{-10}$ dilution using sterile saline. Each ten mice were injected $\mathrm{S} / \mathrm{C}$ with $0.1 \mathrm{ml}$ from each bacterial dilution, another ten mice were left as a control and injected with sterile saline. Mortalities were observed and $L_{50}$ was calculated according to Reed and Muench (1938).

\section{Mean Death Time (MDT)}

It was done to the recently isolated strains and calculated as described by Hanson and Brandly (1955) according to the following formula:

MDT =

(No. of dead at $\mathrm{x}$ hours) $\mathrm{X}(\mathrm{x}$ hour $)+($ No. of dead at $\mathrm{y}$ hour $)$ 


\section{Vaccine preparation}

The monovalent vaccine (inactivated formalized) was prepared for each serotype of recent isolates of $P$. multocida according to Borkowska et al. (1996).

\section{Determination of log protection}

The active mouse protection test was carried out as described by Ose and Muenster (1968). The mice were divided into six groups, 250 mice in each, designated $A, B, C, D, E$ and $F$. Each group of mice from $A$ to $E$ was inoculated $S / C$ by one of the monovalent 5 vaccines (inactivated formalized vaccine) in two doses at a dose of 0.2 $\mathrm{ml} /$ mice ( 2 weeks interval). The mice of group $\mathrm{F}$ were kept as control. Each group was further divided into 5 subgroups, 50 mice in each for receiving challenge homologous and heterologous inoculum (after 2 weeks from booster dose). On the day of challenge, groups of vaccinated and control were challenged with dilution from -1 to $10 \log 10$ at a dose of $0.1 \mathrm{ml} /$ mice $S / C$ in which the minimum lethal dose $\left(L_{50}\right)$ was calculated for each group of mice, vaccinated and control groups based on accumulated death on the $7^{\text {th }}$ day using Reed and Muench (1938) method. The $\left(L_{50}\right)$ of the vaccinated mice was compared to the $\left(L_{50}\right)$ of non-vaccinated mice. $A$ requirement of 2 logs of protection is necessary to qualify the prepared vaccine as index of protection (Ose and Muenster, 1968).

\section{Rabbits}

Fifty-four rabbits with an average body weight of 2-2.5 kg were obtained from private farm and kept under hygienic measures. The rabbits were proved to be fully susceptible to the $P$. multocida by serological testing of random samples. These rabbits were vaccinated with 2 doses of currently vaccine at a dose of $2 \mathrm{ml} / \mathrm{rabbit} \mathrm{S/C}$ (formalized inactivated vaccine) 2 weeks interval, then challenged with $P$. multocida homologous and heterologous strains (recent isolated strains) to determine the immunogenic properties of recent isolates in comparison with current vaccinal strains..

\section{RESULTS AND DISCUSSION}

Pasteurella multocida infection is a constant serious disease problem in rabbits, and in fact it is the major cause of mortality in large rabbitaries through the world (Flatt, 1974). The incidence in rabbitaries varies greatly depending on sanitation, ventilation, genetic resistance and vaccination.

Thirty $P$. multocida isolates were obtained from 150 collected samples of infected and recently dead rabbits as proved by bacteriological examination and biochemical characterization. These isolates, as shown in Table 1, belonged to serotypes $A, B$ and $D$ in which $4,2,8,7$ and 6 isolates belonged to serotypes $A: 3$, 
$A: 3,5, A: 12, B: 2$ and $D: 6$ respectively. Uncommon isolates belonging to serotypes D:12 (2 isolates) and A:4 (one isolate) were obtained. These results agreed with Karl (1966), Chengappa et al. (1982) and Mohamed (1998) who found that the most common field isolates were serotypes A:3, A:12, D:6, capsular types $C$ and B. From the same Table, the results revealed that the cross-reaction occurred in a number of isolates ( $A: 3,5$ and $A: 3)$. These results were observed by Okerman and Spanoghe (1980), Carter and Chengappa (1981).

The investigation on immunity against $P$. multocida is frequently carried out on white mice because of their low price and high sensitivity to infection with the organism. The results illustrated in Tables ( 2 and 3 ) indicated the substantial differences in virulence for mice. Isolates $A: 3, A: 3,5$ and $B: 2$ were highly pathogenic causing death within 18-24 hours, but those of types A:12 and D:6 showed moderate pathogenicity and killed mice within 36-72 hours. Meanwhile, types A:4 and D:12 are of low virulence and killed mice in more than 72 hours. These results are in agreement with Borkowska et al. (1995), Okerman and Spanoghe (1980), Okerman et al. (1978), Ose and Muenster (1968), who studied virulence of $P$. multocida strains isolated from rabbits. Such isolates obtained from septicemic cases revealed high pathogenicity, but those from typical catarrhal infections showed moderate or mild virulence. In this study, the strains of very low pathogenicity and did not cause any problem in field ( $A: 4$ and D:12) were ignored, and the comparative study was done with field strains that caused high mortality.

From data in Table 4, it was found that mice vaccinated with monovalent vaccine of recent isolates and challenged with homologous and heterologous $P$. multocida strains, gave good immunological value with homologous strains. Meanwhile, this vaccine failed to protect mice against heterologous challenge.

The previous results indicated that occurrence of partial cross-immunity is contributed to the presence of somatic type 3 (A:3,5 and A:3). These results are in agreement with Okerman and Spanoghe (1980) who found that the occurrence of partial cross-immunity is contributed to the presence of somatic antigen type 3 in some strains. Also, the results showed that the protective value of vaccines was not attributed to the capsular antigen of strains examined, but may be related with their somatic antigen, as previously confirmed by Borkowska et al. (1995).

From results reported in Table 5, it was noticed that the rabbits vaccinated with currently used vaccine and challenged with the same serotypes (homologous serotypes), gave good protection, and when challenged with heterologous serotypes gave various protection values. These results may be due to partial cross-protection among strains of various serotypes. Also, the results indicated that no protection was 
noticed in vaccinated rabbits when challenged with recent isolated serotypes $B: 2$ and $D: 6$. This may be due to absence of these serotypes in the currently used vaccine.

In this work, we noticed that the appearance of disease in little farms in spite of the vaccination may be due to bad management or wrong vaccination. Also, isolation of $P$. multocida serotypes B:2 and D:6 in some farms causes pathological conditions in these farms. This may be due to presence of large animal farms near rabbit farms. This problem is very easy to treat by preparing autogenous vaccine. These results agreed with Borkowska et al. (1996) who found that the preparation of the vaccine must be prepared from most frequently isolated rabbit strains and selecting the strains with the most immunogenic properties.

From the previously obtained results, it could be concluded that the preparing of autogenous vaccine against rabbits Pasteurella infection is recommended as it is the best method to control the disease when showing any new immunogenic isolates even in sporadic cases.

Table 1. Recent capsular and somatic serotypes from rabbits field isolates of $P$. multocida.

\begin{tabular}{|c|c|c|c|c|c|c|c|}
\hline \multirow{3}{*}{ Somatic } & \multirow{3}{*}{ Capsular } & \multicolumn{5}{|c|}{ Strain origin } & \multirow{3}{*}{ No. of isolate } \\
\hline & & \multirow{2}{*}{$\begin{array}{c}\mathrm{I} \\
\mathrm{NP}\end{array}$} & \multicolumn{3}{|c|}{ II } & \multirow{2}{*}{$\begin{array}{c}\text { III } \\
\text { Lung }\end{array}$} & \\
\hline & & & NP & $\begin{array}{c}\text { Middle } \\
\text { Ear } \\
\end{array}$ & Abscess & & \\
\hline 3 & A & & 2 & & & 2 & 4 \\
\hline 3,5 & A & & 1 & & & 1 & 2 \\
\hline 12 & A & & 3 & 2 & 1 & 2 & 8 \\
\hline 4 & $A$ & 1 & & & & & 1 \\
\hline 2 & B & & 2 & & 1 & 4 & 7 \\
\hline 6 & D & & 2 & & 1 & 3 & 6 \\
\hline 12 & $\mathrm{D}$ & 2 & & & & & 2 \\
\hline \multicolumn{2}{|c|}{ Total No. of isolates } & 3 & 10 & 2 & 3 & 12 & $30 *$ \\
\hline
\end{tabular}

NP: Nasopharynx

I: $\quad$ Diseased animals with very low symptoms and less common types.

II: $\quad$ Diseased animals with sever symptoms.

III: Dead animals (recently dead and make PM).

* These number of isolates isolated from 150 samples. 
Table 2. The relationship between virulence of the organism (time of death in hours) and its serotype and the organ of isolation.

\begin{tabular}{|c|c|c|c|c|c|}
\hline Virulence & Colony type & Time of death (hours) & No. of isolates & Serotype & Organ of isolation \\
\hline \multirow{5}{*}{ Highly virulent } & \multirow{5}{*}{ Irredescent } & \multirow{3}{*}{ Less than 24 hours } & 3 & $A: 3$ & \multirow{3}{*}{$\begin{array}{l}\text { Nasopharynx } \\
\text { Internal organ }\end{array}$} \\
\hline & & & 2 & $A: 3,5$ & \\
\hline & & & 5 & $\mathrm{~B}: 2$ & \\
\hline & & \multirow{2}{*}{ In 24 hours } & 2 & $\mathrm{~B}: 2$ & \multirow{2}{*}{ Abscess } \\
\hline & & & 1 & $A: 3$ & \\
\hline \multirow{4}{*}{$\begin{array}{l}\text { Intermediate } \\
\text { virulent }\end{array}$} & \multirow{2}{*}{ Irredescent } & \multirow{2}{*}{$36-48$ hours } & 5 & $A: 12$ & \multirow{4}{*}{$\begin{array}{c}\text { Nasopharynx } \\
\text { Internal organ } \\
\text { Ear } \\
\text { Abscess }\end{array}$} \\
\hline & & & 5 & D:6 & \\
\hline & \multirow{2}{*}{ Mucoid } & \multirow{2}{*}{ In 72 hours } & 3 & $A: 12$ & \\
\hline & & & 1 & $\mathrm{D}: 6$ & \\
\hline \multirow{2}{*}{ Low virulent } & \multirow{2}{*}{ Blue } & \multirow{2}{*}{ More than 72 hours } & 1 & $A: 4$ & \multirow{2}{*}{$\begin{array}{c}\text { Nasopharynx (with very mild } \\
\text { symptoms) }\end{array}$} \\
\hline & & & 2 & $\mathrm{D}: 12$ & \\
\hline
\end{tabular}


Table 3. Determination of minimum lethal dose $\left(\mathrm{LD}_{50}\right)$ of recent $P$. multocida serotypes isolated from rabbits.

\begin{tabular}{|c|c|c|c|c|c|}
\hline \multicolumn{2}{|c|}{ Highly virulent } & \multicolumn{2}{c|}{ Moderate virulent } & \multicolumn{2}{c|}{ Low virulent } \\
\hline Serotyping & $\mathrm{LD}_{50}$ & Serotyping & $\mathrm{LD}_{50}$ & Serotyping & LD $_{50}$ \\
\hline $\mathrm{A}: 3$ & $10^{-9.4}$ & $\mathrm{~A}: 12$ & $10^{-8.8}$ & $\mathrm{~A}: 4$ & $10^{-6.1}$ \\
\hline $\mathrm{A}: 2,5$ & $10^{-9.8}$ & $\mathrm{D}: 6$ & $10^{-8.9}$ & $\mathrm{D}: 12$ & $10^{-5.9}$ \\
\hline $\mathrm{B}: 2$ & $10^{-9.5}$ & & & & \\
\hline
\end{tabular}


Table 4. Protective value of monovalent vaccine prepared from different Pasteurella multocida serotypes (recently isolated strains) and challenged with homologous and heterologous serotypes in mice.

\begin{tabular}{|c|c|c|c|c|c|}
\hline Challenge strain & \multicolumn{5}{|c|}{ Immunization with monovalent vaccine of the following serotypes } \\
\hline Serotype & $A: 3,5$ & $A: 3$ & $A: 12$ & $\mathrm{~B}: 2$ & D:6 \\
\hline$A: 3,5$ & 4.90 & 4.70 & 1.15 & 1.45 & 0.96 \\
\hline$A: 3$ & 4.68 & $4.84 * *$ & $1.26 *$ & $1.40 *$ & $0.88 *$ \\
\hline$A: 12$ & $1.75^{*}$ & $1.65 *$ & $3.19 * *$ & $1.59 *$ & $0.98 *$ \\
\hline $\mathrm{B}: 2$ & $0.98^{*}$ & $0.92 *$ & $0.79 *$ & $4.98 * *$ & $0.73 *$ \\
\hline D:6 & $0.88^{*}$ & $0.98 *$ & $0.88 *$ & $1.15 *$ & $3.85 * *$ \\
\hline
\end{tabular}

* Non-protective

** Protective 
Table 5. Results of challenge test in rabbits vaccinated with currently used vaccine and challenged with the field strains (heterologous strains) and vaccinal strains (homologous strains).

\begin{tabular}{|c|c|c|c|c|c|c|c|}
\hline \multirow{2}{*}{\multicolumn{2}{|c|}{ Challenge strains }} & \multicolumn{3}{|c|}{ Rabbits vaccinated with currently used vaccine } & \multicolumn{3}{|c|}{ Non-vaccinated rabbits } \\
\hline & & \multirow{2}{*}{$\begin{array}{c}\text { No. of rabbits } \\
4 \\
\end{array}$} & \multirow{2}{*}{$\begin{array}{c}\text { No. of dead/ No. of } \\
\text { total rabbit } \\
0 / 4\end{array}$} & \multirow{2}{*}{$\begin{array}{c}\text { Protection \% } \\
100 \% \\
\end{array}$} & \multirow{2}{*}{$\begin{array}{c}\text { No. of rabbits } \\
2\end{array}$} & \multirow{2}{*}{$\begin{array}{c}\text { No. of dead/ No. of } \\
\text { total rabbit } \\
2 / 2 \\
\end{array}$} & \multirow{2}{*}{$\begin{array}{c}\text { Protection \% } \\
0 \% \\
\end{array}$} \\
\hline \multirow{5}{*}{ 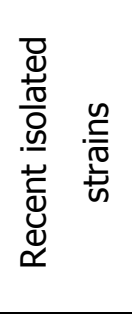 } & $A: 3,5$ & & & & & & \\
\hline & $A: 3$ & 4 & $1 / 4$ & $75 \%$ & 2 & $2 / 2$ & $0 \%$ \\
\hline & $\mathrm{A}: 12$ & 4 & $2 / 4$ & $50 \%$ & 2 & $2 / 2$ & $0 \%$ \\
\hline & B:2 & 4 & $4 / 4$ & $0 \%$ & 2 & $2 / 2$ & $0 \%$ \\
\hline & D:6 & 4 & $4 / 4$ & $0 \%$ & 2 & $2 / 2$ & $0 \%$ \\
\hline \multirow{4}{*}{ 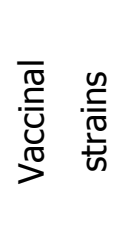 } & 5:A & 4 & $0 / 4$ & $100 \%$ & 2 & $2 / 2$ & $0 \%$ \\
\hline & 8:A & 4 & $1 / 4$ & $75 \%$ & 2 & $2 / 2$ & $0 \%$ \\
\hline & 9:A & 4 & $0 / 4$ & $100 \%$ & 2 & $2 / 2$ & $0 \%$ \\
\hline & $\mathrm{D}: 2$ & 4 & $1 / 4$ & $75 \%$ & 2 & $2 / 2$ & $0 \%$ \\
\hline
\end{tabular}




\section{REFERENCES}

1. Borkowska-Opaka, B., Jurga Irenrutkowska and Truszczynski Marian. 1995. Pasteurella multocida serum level in rabbits vaccinated against Pasteurellosis. Bull. Vet. Inst. Pulway, 39: 109-113.

2. Borkowska-Opaka, B., Jurga Irenrutkowska and Truszczynski Marian. 1996. An attempt to evaluate the efficacy of vaccines against pasteurellosis in rabbits. Bull. Vet. Inst. Pulway, 39: 9-12.

3. Carter, G.R. 1955. Studies on Pasteurella multocida identification of serological types. Am. J. Vet. Res., 16: 481-484.

4. Carter, G.R. and M.M. Chengappa. 1981. Identification of type B and E Pasteurella multocida by counter immunoelectrophoresis. Vet. Rec., 108: 145-146.

5. Chengappa, M.M., M.X. Meyersrc and G.R. Carter. 1982. Capsular and somatic types of Pasteurella multocida from rabbits. Can. J. Comp. Med., 46: 437-439.

6. Flatt, R.E. 1974. Bacteriological diseases in Weisbroth S.H.. The Biology of the laboratory rabbits. New York, Academic Press Inc., 194-232.

7. Hanson, R.P. and C.A. Brandly. 1955. Identification of vaccine strains of NDV. Sci., 122-156-157.

8. Hagen, K.W. 1966. Enzootic pasteurellosis in domestic rabbits. II. Strain types and methods of control. Lab. Anim. Sci., 16: 487-491.

9. Hedleston, K.L., J.E. Gallagher and P.A. Rabers. 1972. Fowl cholera gel diffusion precipitin test for serotyping Pasteurella multocida from avian species. Avian Dis., 16: $925-936$.

10. Karl L.W. 1966. Enzootic pasteurellosis and methods of control. Lab. Animal Care, 16 (6): 325-334, printed in USA.

11. Mohamed, H. 1998. Evaluation of different vaccination protocol of Pasteurella multocida in rabbits. Thesis, M.V.Sc. Fac. Vet. Med., Cairo University.

12. Okerman, L., L. Spanoghe and R.M. Bryker. 1978. Experimental infection of mice with Pasteurella multocida strains isolated from rabbits. J. Comp. Pathol., 89: 5155. 
13. Okerman, L. and L. Spanoghe. 1980. Immunity induced in mice by Pasteurella multocida strain isolated from rabbits. Zntbl. Vet. Med., Reihe, B27: 759-765.

14. Ose, M.S. and M.S. Muenster. 1968. A method for evaluation of vaccines containing Pasteurella multocida. Am. J. Vet. Res., 29 (9): 1863-1866.

15. Percy, D.H. and J.L. Bhasin. 1987. Control of pasteurellosis in rabbits: An over view. Lab. Anim., 16: 28.

16. Reed, L.J. and H. Muench. 1938. Simple method of estimating 50 percent end point. Amer. J. Hyg., 27: 793-799. 
دراسة الضر اوة والاستجابة المناعية لعترات الباستريلا مالتوسيدا المعزولة حديثاً من الأرانب المصابة

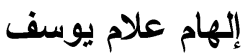

معزة بحوث الأمصال و اللقاحات البيطرية - العباسية - مركز البحوث الزراعية - وزارة النزراعة -

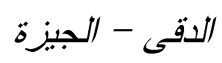

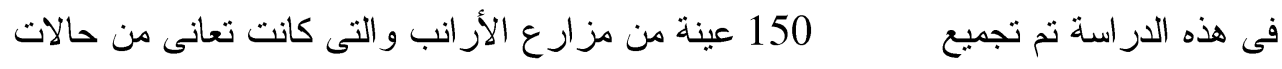

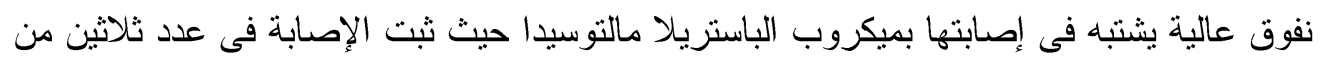

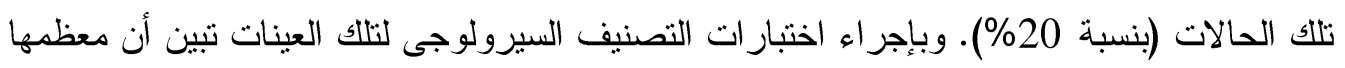

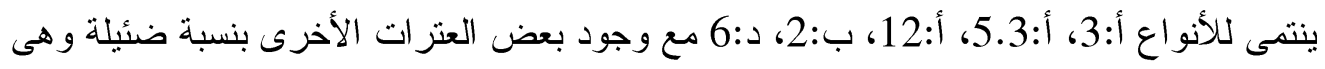

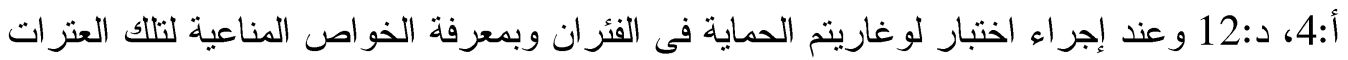

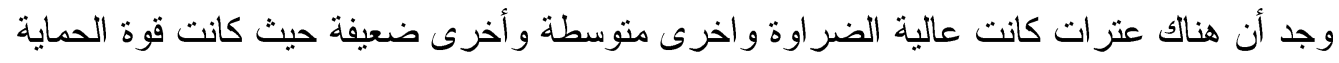

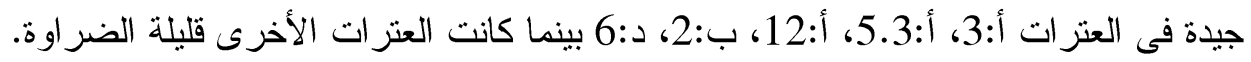

وقد تم فى هذه الدراسة تحصين الأرانب باللقاح المحلى و إجراء اختبار التحدى بنفس

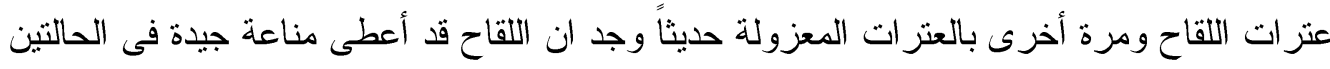
فيماعدا العترتين المعزولتين حديثاً ب:2، د:6. 
